\title{
Mentoring first year police constables: Police mentors' perspectives.
}

\author{
Mark A Tyler \\ University of Southern Queensland \\ William E McKenzie \\ Queensland Police Service
}

Mentoring as a tool for the support and development of novices in many organisations has been considered a putative success. Nevertheless, the literature reveals a paucity of reporting of the mentoring strategies used within the policing profession within Australia. What mentoring is and how it is deployed from Police Mentor's perspective is the focus of this article. This inquiry will shed light into this contextual gap by illuminating the mentoring experiences of 13 police officers from the district headquarters of a regional city in southeast Queensland. These officers, who presented with varying lengths of police service, were interviewed to ascertain their experiences of being a mentor, and to investigate if they deployed what could be interpreted as a particular model of mentoring. Also considered were, their perspectives and impressions of undertaking the role of mentor, their descriptions on how they mentored, and their preparedness for mentoring. The interviews revealed a group of police officers that reported a belief in the mentoring process. Further, they considered themselves personally prepared for the role of mentor, and related this preparedness to either past experiences of being mentored, or past experience in the role itself. They placed little emphasis on formal training as a mentor, and more often than not, mentored in isolation. These officers rarely requested any collegial support from fellow mentors. The data highlighted several implications for mentoring within the Queensland Police Service, one of which includes the effectiveness of present formal preparation for Mentors.

Key Words: Mentors, mentoring, police, police training, interview, evaluation, qualitative methods. 
Beginning a profession appears as a crucial time for individuals newly trained in the art and or science of their profession, it appears that the support these individuals receive is crucial to their immediate experience and central to "their longer-term professional learning" (Carter \& Francis, 2001, p. 249). In this paper we discuss mentoring as one form of this professional support. In particular we focus on mentor experience within a regional police headquarters in southeastern Queensland, Australia.

Boud and Garrick (1999) take the position that learning through work occupies and important role in maintaining and developing vocational practice. This is the case for many workers as the workplace offers an accessible location to attain vocational knowledge and skill. For the training of police officers in Queensland, workplace training is considered an essential adjunct to the formal training presented in academy environments (QPS, 2011). The following reports on how mentoring as a part of workplace learning is experienced from the police mentor's perspective.

\section{Literature review}

In recent times the breadth of the literature published in relation to mentoring in the workplace is considerable. For example, mentoring in initial teacher education (Carter \& Francis, 2001), mentoring in the health profession (Byrne, \& Keefe, 2004) and mentoring in academia (Sedlacek, Benjamin, Schlosser, \& Sheu, 2008) are just a few representations. Most communicate, in chorus, that early career mentoring is desirable. Notable publications on mentoring also highlight its value as being of benefit to an individual's career (Allen, Eby, Poteet, Lentz \& Lima, 2004) and enabling an improvement in organisational performance (Payne \& Huffman, 2005; Garvey \& Galloway, 2002).

An accepted definition of mentoring appears distant. Bozeman and Feeney (2007) note a collective sample of 13 definitions that all identify various nuances that cloud conceptual clarity. For this research we have deployed the following definition:

Mentoring: a process for the informal transmission of knowledge, social capital, and psychosocial support perceived by the recipient as relevant to work, career, or professional development; mentoring entails informal communication, usually face-to-face and during a sustained period of time, between a person who is perceived to have greater relevant knowledge, wisdom, or experience (the mentor) and a person who is perceived to have less (the protégé). (Bozeman \& Feeney, 2007, p. 731)

The context of mentoring is varied yet the doing of mentoring has similarities. Clutterbuck (2004) suggests that data collected from "practitioner accounts" (p. 42) illustrate mentors' competence in their role through their responding to protégés in terms of degrees of directiveness. He suggests that directiveness for mentors has two dimensions that lie on a continuum between stretching protégés and nurturing them. Directive stretching is similar to coaching where mentors encourage the protégé to engage in new things. The mentor in this 
instance acts as a critical friend and motivates particular responses from protégés. Non-directive nurturing is considered the opposite. Here the mentor deploys a personal support role. Clutterbuck equates this role with that of a counsellor. The second dimension is directive nurturing, a "guardian - someone who takes a protective interest" (p. 47). This role is more akin to advocate and advice giver. The accompanying pole is that of non-directive stretching. Here the mentor enables the protégé to "become more self- resourceful" (p. 47).

Clutterbuck goes onto point out that mentors also show competency related to engaging in self-managed learning, "they seize opportunities to experiment and take part in new experiences" (p. 52).

Mentoring peculiar to policing has had an international focus, yet most appears to emerge from the United States of America (US). The following discussion covers recent examples of note.

Arter (2006) articulates the benefits of police as mentors in community policing. This conceptual paper suggested that police have legitimacy in being role models for at risk youth. Arter supports his position by using the success achieved by the well know Big Brothers Big Sisters of America program (Grossman \& Tierney, 1998) and called for "matching these youth with a police mentor from their community .... an appropriate adult role model" (p. 90). Arter concludes with the need for the concept to be "embraced and supported by middle management and administration" (p. 94).

Mentoring for those newly appointed to leadership positions in the police was the central point of Chaney's (2008) recommendations made as a result of errors that threatened the tenure of police chiefs in Ohio. Chaney, a police chief himself, noted 10 of the most common errors that thwarted the enjoyment of "long and successful careers" (p. 1). Some that were noted were:

- Failure to listen

- Failure to learn to budget properly

- Failure t deal with politics

- Failure to assess the talent pool properly, and

- Failure to take time to assess.

Chaney's central tenant was that those new to leadership positions in the police need not solely rely on experience, but would benefit by engaging with those "who have been in the position, who have experienced the difficulties...and avoided making the mistakes in the first place" (p. 2).

Mentoring as a benefit to police trainees was investigated in Oyo State, Nigeria. Oyesoji and Ayobami (2009), investigating the personal-psychological factors on the career aspirations, and concluded that mentoring was the third causal variable on the career aspirations of police trainees. Oyesoji and Ayobami noted that these results were in accord with the seminal work of Aree and Chay (1994) who concluded that significant career development was a result of the influence of mentoring. 
Utilising the extensive skills and knowledges of police officers that are of retirement age in London Metropolitan Police Service (MPS) by way of engaging them in mentoring roles within the service, was a recommendation put forward by Flynn (2010). In his research into extending the capacity of retiring police officers, Flynn interviewed seven senior human resource (HR) managers and two trade union representatives within the MPS. The HR mangers noted the utility value that older experienced police officers had in "teaching new recruits tacit on-the-job skills" (p. 384), but also noted the apparent low status of this police work and the apparent "negative stigma attached to this kind of job opportunity for older police officers" (p. 384). Given the currency of this publication, this would suggest that at the time of publication, London MPS did not have a formal mentoring program in place for beginning police officers.

Sprafka and Kranda (nd) published a best practice guide for mentoring through the International Association for Chiefs of Police (US based). This document is of note because it clearly articulates to its specific audience a concept of mentoring, benefits for both police mentors and protégés, and their roles and responsibilities. What also is of note in this publication is the distinction between field training officer (FTO) and the mentor roles. Sprafka and Kranda stipulate a separation between the provision of guidance and support to protégés, and performance evaluation. They state, "mentoring is not performance evaluation" (p. 6, italics in original). This document appears as a generalised position on mentoring that highlights its beneficial character; yet (assumed because of the publication's audience and purpose), lacks direct citation to particular research that it appears to be informed by. This publication's interest to this study is the differentiation between performance evaluation and the provision of support; a point that will be return to in discussion in relation to the findings that emerged from this study.

Specific research into mentoring within US police forces was conducted by Fagan and Ayrers (1985) that advanced the position that the training of police officers in Kentucky, Texas and Pennsylvania was "not complete until they work the streets under the guidance of a seasoned veteran" (p. 8). Their survey received 70 respondents who answered questions about being a protégé and mentor. Findings included the noting of the valuable mentor traits of: dedication to the job, tactfulness, patience, independence and honesty; and a significant relationship between job satisfaction and having a mentor. As an adjunct to the survey the authors also reported on typical FTO programs for police that used mentoring as their central strategy. Factors for consideration in the deployment of these programs included: too much standardisation that hindered FTOs in contributing their unique personality and style to training protégés, difficulty in being a mentor and evaluator to the same protégé, and a need to match a protégé with an FTO.

Many have highlighted the benefits of mentoring to the mentor. One specific example is the experience of mentoring derived from the nursing profession. Mobley, Gray and Estep (2003) highlighted that nursing mentors received credit for enabling the recertification of graduate students. Grossman (2007), again referring to a nursing context, articulates that the general benefits of being a 
mentor are, for example, increased self esteem, increased admiration for individual skills of being a mentor, increased leadership succession, increased motivation toward their career and the fulfilling of a generativity need by giving something back to their profession. Yet, Grossman also the points out that these benefits appear to occur despite the inadequate support that mentors have received from "their own institution[s]" (p. 111).

Billett (2003) stands as another example of the effect that mentoring has on the mentors themselves. In an Australian manufacturing workplace Billett, whilst focusing on the capacity for competence in mentoring, found that mentors generally thought that mentoring was effective. Having said that, Billett reported that the mentors in this study noted that their "mentoring tasks rendered their work more demanding and intense" (p. 109), that management tended to not acknowledge their work and that success was equated with the mentors' efforts themselves rather than any additional support. Other inhibiting factors included production demands, time constraints and the attitudes of protégées.

There is a gap in the research into the phenomena of mentoring within an Australian police force context. The research reported in this paper is therefore arguably original and timely. Given the recent public scrutiny of policing generally (Hopkins, 2009) insight into the processes through which new recruits become acculturated to policing is considered of value. This paper now moves to the discussion on the context of this study and its design.

\section{Context}

The background for this study is a district police station located in a regional south-east Queensland city. The station is the $6^{\text {th }}$ largest of the 32 police training stations located across Queensland. With a gazetted strength of 94 police officers Toowoomba station is one of the eight largest stations in Queensland. Approximately 80 officers comprise the general duties work-unit in which first year training of police officers principally takes place. About 35 officers are designated Field Training Officers (FTOs) and a similar number are first year constables at varying stages of progression through their probationary training program.

Upon graduation from a six-month recruit-training program, at either of the two QPS Academies located at Brisbane and Townsville, all recruits enter a probationary operational (on-the-job) training period of twelve months as First Year Constables (FYCs). Training is competency-based with satisfactory performance across twenty areas of competency required prior to confirmation of FYCs as sworn-officers. This twelve month operational period involves FYCs being partnered with experienced officers, the FTOs, and engaging as a twoperson car crew or patrol crew in the full ambit of emergency response duties (also referred to as first-response policing, or general duties policing).

The first eight weeks of the FYC's on-the-job training is called the 'mentor phase'. Usually the FYC or protégée is restricted to two periods mentoring with two FTOs over four weeks respectively. This mentoring period may increase depending on operational needs. The next phase of their on-the-job training is 
identified as the 'general phase' of training. This is the remainder of the training that follows the mentor phase. The only requirement is that a constable should be rostered with an FTO whilst on patrol duty.

Working within general duties, officers are divided into 5 operational teams consisting of about 15 to 16 members each. Rostering across three shifts over each twenty-four hour employs one team per shift. For the majority of the training period then, a FYC will generally perform patrols with only the six or seven FTOs in the team to which the constable is allocated.

\section{Research design}

This study takes a qualitative research orientation were we, the authors, have taken the perspective of interpretivist enquirers (Glesne, 1999). Therefore we are seeking understandings of the participant's, in this case selected FTOs', social constructs and constructions (Hacking, 1999) in relation to undertaking the role of mentor. Data are the FTOs' voice and collected by way of semi-structured interviews (Arksey \& Knight, 1999). Thirteen FTO's were interviewed. Selection of participants was purposive (Kemper, Stringfield and Teddlie, 2003). Convenience around operational requirements was one influencing factor, too the need for varied representation in operational and mentor experience.

The 13 officers interviewed ranged in length of service from two years to thirty years. Seven of the officers ranged between two - five years service and the other six ranged between 11 - 30 years service. At the time of being interviewed all officers had acted as a trainer during at least two four-week mentor phases, and had regularly worked with FTOs to varying degrees.

The FTOs interviewed were asked of their personal impressions of mentoring, how they mentored, their own experiences of mentoring, what they perceived as the most important element of mentoring and also the most cumbersome aspect of it, when mentoring would stop and their perceptions of themselves as mentors. In line with one aim of the inquiry, to obtain a rich description of police mentor's perspectives on what mentoring is and how it is deployed in the study setting, rich and deep descriptions were sought. The participants were not provided with the questions in advance of the interviews and whilst no time limits were placed on the interviews all interviews ranged between about 1 to 1.5 hours in length. All interviews were audio recorded and data were transcribed. Participant responses were first read and re-read deploying an iterative process that move analysis to deeper understandings (Foggatt, 2001). Responses obtained for each of the questions were subjected to thematic analysis (Joffe and Yardley, 2004). In the interests of confidentiality, the participants remain anonymous. In the reporting of this data all participant have been assigned with pseudonyms. Throughout the next section certain mentor voice has been reported in Table 1 and also as part of the analytical discussion. In the latter instance, this voice is identified with inverted commas. In some specific instances the mentor is identified and in others, where more generalised analysis takes place, they are not. The deployment of this technique was grounded in our need to bring the analytical discussion closer to the mentors' 
voice, thereby enabling greater richness in the discussion than that achieved through the sole use of tables.

\section{What the mentors said}

\section{Impressions of Mentoring}

All interviews started with a request for the participants to give their general impressions of mentoring. Answers varied in depth and had an overarching theme that was akin to a parental 'under my wing' type guidance. All FTOs indicated the need for mentoring as a means of introducing policing. Answers relating to this need ranged from "I think it's a really good idea" to "absolutely necessary". Specifically, mentoring to these police trainers meant engagement in "an important valuable sort of teaching", and having to "make sure that they're [protégées] headed in the right direction". From one participant, Ann, was the articulation of what she saw as a mentor's multi-roles, "a role-model, a confidant, a baby sitter; sometimes a trainer". Fundamental in all responses was the theme of enabling protégées in the process of "learning the ropes of the job". Two officers mentioned that mentoring within the mentioned 8-week period was central to the protégées future success as a police officer, suggesting that if appropriate engagement with reasonable mentors did not occur, the protégée's fit with the job may become incongruous. Even though no negative view of mentoring was indicated, one police trainer did raise a concern about inexperienced trainers mentoring. He raised the observation that due to the sheer numbers of recruits graduating from the police academy, more requests were placed on operational personnel to step up into the role of FTO and to take on first year protégées. His concern was around his observation that these police trainers were less experienced and wondered how this might influence the quality of the mentoring they provide. This particular officer had thirty-five years experience as an operational officer.

\section{How did they mentor?}

Responses to the question "How do you mentor?" produced varied responses. These data indicated a breadth of difference in how each one of the participant FTOs mentored and central to this difference appeared to be the officers' priorities.

Presented in Table 1 are extracts from the FTOs' responses. Whilst complete transcripts of their responses to the question indicated similarities, for example, mentoring by being a role model, these extracts show individual differences in how mentoring is approached and enacted by these officers. Ensuring that grounding is given in basic routine, choices between being an observer and active participant during the beginning of the mentoring period, and a concern for clear communication between experienced officer and protégée are examples. Yet the two extracts that are standouts for the researchers are firstly, that which emphasises a need to have one's "bum covered" and secondly, a concern for ensuring that protégées are not belittled for their mistakes, "Mistakes are expected" reminded Michael. 
Table 1: Extracts from participant responses to the question: How do you mentor?

\begin{tabular}{|l|l|}
\hline Police Officer & Response \\
\hline Peter & Lead by example. \\
\hline Paul & $\begin{array}{l}\text { I give the first years basic outline of how I want } \\
\text { things done and I do things... just to a point, let } \\
\text { them go on their own and see how they go. }\end{array}$ \\
\hline Mary & $\begin{array}{l}\text { Well I'll normally ask if , you know, do you } \\
\text { want to just observe what I'm doing first or, } \\
\text { you know, do you want to jump in? }\end{array}$ \\
\hline Ged & $\begin{array}{l}\text { I try to remain fairly laid back. Try and keep } \\
\text { them relaxed }\end{array}$ \\
\hline Ann & $\begin{array}{l}\text { Tell them not to stress too much. } \\
\text { [To] throw them in at the deep end and watch } \\
\text { them sink its not a good experience. }\end{array}$ \\
\hline Henry & $\begin{array}{l}\text { We do a log of everything we do, so I am a little } \\
\text { bit particular. I want certain information so my } \\
\text { bum's covered. }\end{array}$ \\
\hline Callum & $\begin{array}{l}\text { For the first time, if it's a particular job that the } \\
\text { person hasn't done before, I make sure that } \\
\text { they do every step of the job themselves. }\end{array}$ \\
\hline Luke & $\begin{array}{l}\text { I try and make sure that I brief him or her } \\
\text { thoroughly on what we are about to do and } \\
\text { where an activity is. }\end{array}$ \\
\hline Joseph & $\begin{array}{l}\text { Apply the skills, and the person that has those } \\
\text { skills imparted to, can take them on and use } \\
\text { them. }\end{array}$ \\
\hline $\begin{array}{l}\text { I sat down with the young fella before we went } \\
\text { out and just basically explained to him how I } \\
\text { do things and also explained to him that he's } \\
\text { going to work with a variety of other officers, } \\
\text { especially in his first year, and everyone does } \\
\text { things slightly differently. }\end{array}$ \\
\hline $\begin{array}{l}\text { I will try and assess what sort of wording style } \\
\text { is going to be most successful for them; } \\
\text { stand next to them; not to make them feel as } \\
\text { though they are unknowledgeable or stupid. }\end{array}$ \\
\hline $\begin{array}{l}\text { I enjoy engaging with people. Having them, the } \\
\text { FYC, sitting beside me probably prompts me to } \\
\text { be more particular. }\end{array}$ \\
\hline $\begin{array}{l}\text { Guiding them through. } \\
\text { You try and give them a lot to do you know for } \\
\text { their confidence. }\end{array}$ \\
\hline
\end{tabular}

There were two themes that emerged in relation to posterior protection. Firstly, and in no particular order of priority, was the articulated need to ensure that little reason should be given for the "hierarchy" to offer criticism on how an officer executed her/his duties, hence protégées should aim at getting it right as soon as possible, and secondly, the need to ensure that the protégée was apt at backing up their mentor partner if the situation warranted it, especially in public interactions where violence was present.

Also reported was a requisite to actively tell protégées “don't be frightened to ask questions". These mentors consciously wanted their protégées to self-initiate the traversing of knowledge gaps and acknowledged that they did not always know where these gaps lie. They preferred to be prompted by their protégées 
through them actively seeking knowledge. But, perhaps the most salient observation came from Joseph, who pointed out that no two police officers go about policing exactly the same way and advised his protégées to be attuned to this variety, and to use it to their advantage.

\section{The "office"}

In relation to active mentoring, that which relates to actual communication with protégées in relation to learning the peculiar and routine aspects of a job, whether they be testing knowledge, planning action, debriefing or delivering correction, and where this is likely to occur, these FTOs reported that the car offers one of the most convenient environments. To the question "Why the car?" Moses responded, "Cause that's my office." The reasons disclosed by officers can be summarised as, the car offering space were:

- one can get undivided attention

- prior knowledge can be easily tested

- privacy is assured

- the most recent and updated information is received in relation to the jobs, and

- issues can be dealt with in the here and now, it is immediate.

Michael suggested, "That's the best way of doing it I suppose, the sooner the better".

Nevertheless, the "office" also extended to "on the scene", but out of earshot of the public, and during periods "back at the station". The latter was related to the associated "paperwork". This included engaging with QPRIME (Queensland Police Records and Information Management Exchange), the principal computer operating system for data recording and retrieval, and brushing up on different procedural and regulation changes. One FTO, Callum, talked of taking time in any location to engage in what he called "soldier's fire" where a topic of policing was highlighted up by him and he would "test" the protégées on the area's they were a bit "grey on". It appeared that his aim was to seek reflexive responses that were close to "correct" but without too much "thinking time", a skill that he thought provided an operational advantage.

\section{The most important element of mentoring}

A variation in perspectives as to what these FTOs thought was the most important element of mentoring was evident. These emerged from three themes; the personal qualities and skills of the mentor, the character of the protégée and the medium of interpersonal engagement. Starting with the latter because it included both mentors and protégées, successful interpersonal communication was highlighted as being essential. The mentors' ability to communicate clearly and concisely with protégées was voiced as important. The protégées' ability to be confident enough to ask questions of mentors and "speak confidently with the public" because "essentially [they have] got to get people talking" was considered essential. Further, were the personal characteristics of the mentor. Some FTOs highlighted the need for earning the protégées' respect, for without this "you can tell them until you are blue in the face and they will take on very little". It was evident that some FTOs actively built a position that invited the bestowing of respect, these officers talked about "showing confidence and 
knowledge" having the ability to answer big questions" and showing "authenticity in my behaviour". Displaying tolerance and patience toward the protégées and leading by example were also commonly voiced. Joseph highlighted the overall sentiment when he said, "Know your own job well and it will rub off on mentees". This suggested that for these mentors their job knowledge and experience had a close relationship with what they saw as successful mentoring.

\section{The experience of being mentored}

Of the 13 participants, eight were able to identify their experience as being formally mentored, three said that they were not mentored, one had not been mentored as a probationary police officer in another Australian state but was mentored when he transferred to the QPS, and one recalled an informal mentoring arrangement some 35 years ago. Those who said they were mentored indicated that they did take on some of the mentoring characteristics of their mentors but were quite discerning about the specific ones emulated. "Being methodological about paper work", "being very open and approachable and not stressing out", "being very good at explaining" and being thorough, were identified as being desirable traits that were emulated. Mentor traits that were demonstrated by these officers' mentors, and were actively avoided were: having "a short temper", "loathing confrontation" and just going through the paper work of mentoring without a wholehearted engagement with the process. Mention was also made regarding avoiding one mentor's tendency toward the public recrimination of protégées. Those who said that they were not mentored acknowledged that their first partner had an influence on their "modus operandi".

\section{What are the most cumbersome elements of mentoring?}

For these police officers the most cumbersome thing about mentoring appeared as the mental and emotional labour employed in "thinking for two". "[I]t's like working two jobs" said Mark. Because of this, the time factor involved in completing a task took "two to three times longer". Luke suggests that it is also the constant "worrying that you're teaching the right thing". Other FTOs also highlighted the protégées safety as something that was constantly on their mind. The majority of these officers also identified the training manual as a source of irritation. With its large list of competencies (that protégées need to demonstrate), and the requirements for its constant updating, it rated as the second highest cumbersome element of mentoring in this corner of the QPS. Even though these two elements dominated conversation on this topic, all indicated that they overall enjoyed being mentors. All indicated that they wouldn't stop mentoring if they had a choice, and that they saw themselves as always mentoring. Mark put it this way, "you are always in a position to tell someone something that you know". This is indicated in the next topic where we asked the FTOs to rate themselves as mentors.

\section{Field Training Officers' self-rating as a mentor}

The interviews were concluded with a final question in which the FTOs were asked to rate themselves on a scale from one to ten on their ability to mentor. 
Most of the officers rated themselves above six. Four of the officers rated themselves "six or seven". Another four rated themselves "seven or eight". Two officers rated themselves eight, one officer a nine and another officer a 10 . The standout was Luke who gave himself two ratings, an eight out of 10 for attitude and a five out of 10 for "every thing else". Possibly Rod was being modest, but what he emphasised was that policing was dynamic and that there was always an element of not knowing. All participants indicated, even the officer who rated himself as $10 / 10$, that they did not "know it all." When asked what it was that would enable them to rate themselves one point higher, they all mentioned it was the future experience and knowledge of policing that they had not yet accumulated as being the major factor involved. Regardless of their length of service as a police officer, all participants highlighted their need to be continually learning.

\section{Implications and recommendations}

In general, this research supported mentoring as a conduit for workplace learning. The perspectives from these police FTOs paint a positive picture of how mentoring is deployed in this regional headquarters of southeast Queensland. Nevertheless, it should be noted that they were not offered an opportunity to give their opinion on how the model could be enhanced.

What the results do offer are some pertinent insights into these mentors' response to engaging their role. These FTOs:

- take on the role of mentor with a degree of pride, and are serious about imparting their operational knowledge and skill

- position the mentoring role as that which should ideally be carried out by experienced personnel

- expend significant mental energy thinking, planning and acting in ways to enhance the learning of their protégées

- care about their protégées, in particularly their safety and protégées' ability to understand and deploy the skill associated with back up

- construct and highlight their identities as suitable for undertaking the mentoring role

- acknowledge the support they receive by way of extra remuneration for undertaking mentoring, but highlight how they are often "time poor" because of the extra time required to "think and plan for two".

- are circumspect about their level of knowledge and skill, highlighting the shared position that they will "never know it all" and emphasise their need to be continually learning, and

- experience various degrees of tension in the role of evaluator and in particular their engagement with the competency check lists used to evaluate the FYCs' performance.

The provision of performance evaluation and support to protégés, whilst highlighted in the literature as a source of concern to mentors (Fagan \& Ayres, 1985) did not appear as an explicit experienced raised by these police trainers. This could be explained through utilising the directiveness/nurturing conceptualisation of mentoring competencies presented by Clutterbuck (2004). In this instance of mentoring, the data suggested the deploying of the directive 
stretching competency associated with coaching. Therefore, these participants' appeared to deploy a behavioural model that concentrated on the 'doing' of police work. Whilst there was some data alluding to the nurturing dimension of Clutterbuck's competencies, for example in statements like "I'm there to reassure, to say that's good", much weight was placed on doing the job right. This was clearly indicated by Ann's statement "I want them to cover certain information so my bum's covered". This is particularly the case when it came to the consequence of doing the job wrong and having one's work come under the scrutiny of supervisors. These FTOs were motivated to enhance performance.

Often, further insights can be gleaned from what is not explicit in the data. These FTOs talked little about sharing their mentoring knowledge or experience with each other. This sharing was only implied in two interviews. How an FTO mentors appears as "personal turf", and comment on or advice was not always welcome from other mentors. We, the researchers, wonder about the possible benefits of instigating an arrangement where mentors get the opportunity to engage in social learning (Burr, 2003). Learning space devoted to the how of mentoring. Where FTOs can share, highlight, challenge and learn from each other about the role they enact on a day-to-day basis.

In regard to the definition proposed at the beginning of this paper (Bozeman \& Feeney, 2007), what could be said about mentoring in this instance? Firstly, this research has reported on the relationship between more experienced workers and less experienced workers. This was a formally organised exercise in the transmission of knowledge and social capital. The support provided appeared more akin to a coaching model associated with the doing of policing. Implicit was the deployment of psychological support to protégés, but there was little evidence that this was explicitly considered by the participants to be a responsibility of the mentors. Even though it was not a focus of this research, there was little anecdotal evidence that the reported mentor relationships enhance the protégés position for advancement within the organisation. Hence, it is arguable whether or not we could label this practice as mentoring. Nevertheless, the practice has been constructed and named by the QPS as mentoring which adds to the various permutations and iterations of mentoring and its defining.

There was also little evidence of an explicit understanding of guided learning which Billett and Boud (2001) would label an understanding of workplace pedagogic practice. This includes the strategies of modelling, coaching, questioning, explaining and using diagrams, to enhance knowledge acquisition in every day experience. Whilst some of the FTOs indicated an implicit application of these strategies, it is our contention that an explicit engagement, through relevant workshops, would enhance the FTOs intentional knowledge and skill transfer to protégées.

Feedback is considered an essential part of enhancing practice. These FTOs reported receiving no feed back from protégées apart from seeing them in operational situations "further down the track". They reported degrees of satisfaction at seeing a past protégée operating effectively. FTO receptivity to 
formal feedback from protégées was not gauged. Nevertheless, the principles associated with professional reflection highlight its utility value. Given these FTOs' professional positioning as being receptive to new knowledge and learning, we would suggest the implementation of a feedback mechanism that was produced in consultation with the FTO mentors.

The data from this research has supported the notion that mentoring as a work place learning tool, as deployed in a regional area of the QPS, was successful. The research was original in that it reported police FTO mentor's perspectives on mentoring. Despite the extra demands at work, mentoring for the participants appeared as an enriching experience. Management support and acknowledgment are implicated in this outcome, along with the implicit idea held by each FTO that they had the personal and professional abilities for carrying out the role. There was no evidence to suggest that because of the extra demands of mentoring, these FTOs would voluntarily relinquish their mentoring roles.

\section{References}

Allen, T. D., Eby, L. T., Poteet, M. L., E., L., and Lima, L. (2004), “Career benefits associated with mentoring for protégés: A meta-analysis", Journal of Applied Psychology, Vol. 89 No. 1, pp. 127-136.

Arter, M. (2006), "Police mentoring: Moving toward police legitimacy", Criminal Justice Studies, Vol. 19 No. 1, pp. 85-97.

Aryee, S., and Chay, Y. (1994), "An examination of the impact of career-oriented mentoring on work commitment, attitude and career satisfaction among professional and managerial employees", British Journal of Management, Vol. 5 No. 4, pp. 241-249.

Arksey, H., \& Knight, P. (1999), Interviewing for social scientists, Sage, London.

Burr, V. (2003), Social Constructionism, Routledge, London.

Billett, S., and Boud, D. (2001), "Participation in and guided engagement at work: Workplace pedagogic practices", available at:

http://aeq.sagepub.com/content/53/1/27.full.pdf+html" (accessed 13 January 2011).

Billett, S. (2003), "Workplace mentors: Demands and benefits. Journal of Workplace Learning, Vol. 15 No. 3, pp. 105-113.

Boud, D. and J. Garrick, Eds. (1999), Understanding learning at work. Routledge, London.

Bozeman, B., and Feeney, M. (2007), "Toward a useful theory of mentoring", Administration \& Society, Vol. 39 No. 6, pp. 719-739. 
Byrne, M., and Keefe, M. (2004), “Building research competence in nursing through mentoring", available at:

http://onlinelibrary.wiley.com/doi/10.1111/j.1547-

5069.2002.00391.x/abstract (accessed 20 December 2010).

Carter, M., and Francis, R. (2001), "Mentoring and beginning teachers' workplace learning", Asia-Pacific Journal of Teacher Education, Vol. 29 No. 3, pp. 251-262.

Chaney, M. A. (2008), “The Police Chief ", available at:

http://policechiefmagazine.org/margazine/ (accessed 20 December 2010).

Clutterbuck, D. (2004), “Mentor competences: a field perspective”, in

Clutterbuck, D. \& Lane, G. (Eds.), The situational mentor, Gower Publishing Ltd, Burlington VT, pp. 42-56.

Fagan, M., and Ayers, K. (1985), "Professors of the street - Police Mentors", FBI Law Enforcement Bulletin, January, pp. 8-13.

Flynn, M. (2010), "Mandatory retirement in the police service: the case of the London MPS”, Policing: An International Journal of Police Strategies and Management, Vol. 33 No.2, pp. 376-391.

Garvey, B., and Galloway, K. (2002), "Mentoring at the Halifax plc (BHOS): A small beginning in a large organization", Career Development International, Vol. 7 No. 5, pp. 271-278.

Glesne, C. (1999), Becoming qualitative researchers: An introduction, Longman, Sydney.

Grossman, J. B., and Tierney, J. P. (1998), “Does mentoring work? An impact study of the Big Brothers Big Sisters program”, Evaluation Review, Vol. 22 No. 2, pp. 403-426.

Grossman, S. (2007), Mentoring in nursing, Springer, New York.

Hacking, I. (1999), The social construction of what?, University Press, Cambridge.

Hopkins, J. (2009), "A study of human rights compliance in police complaint models in US, Canada, UK Northern Ireland and Australia", available at: http://www.humanrightsconsultation.gov.au/www/nhrcc/RWPAttach.nsf/VAP /(966BB47E522E848021A38A20280E2386) Tamar_Hopkins_AGWW7R37ML.pdf/\$file/Tamar_Hopkins_AGWW-7R37ML.pdf (accessed 25 March 2011).

Joffe, H. and Yardly, L. (2004), "Content and thematic analysis”, in Marks, D. and Yardley, L. (Eds.), Research methods for clinical and health psychology, Sage, Thousand Oaks, pp. 56-68. 
Mobley, C. Gray, B., \& Estep. S. (2003), “Growing” nurse practitioners: Mentoring strategies for preceptors. Advance for Nursing Practitioners, Vol 3, pp. 51-54.

Oyesoji, A., and Ayobai, L. (2009), "A path model investigating the influence of some personal-psychological factors on the career aspirations of police trainees: A perspective from Oyo State, Nigeria", Police Practice and Research, Vol. 10 No. 3, pp. 239-254.

Payne, S. C., and Huffman, A. H., (2005), "A longitudinal examination of the influence of mentoring on organizational commitment and turnover", Academy of Management Journal, Vol. 48, pp. 158-168.

Queensland Police Service (QPS). (2011), Queensland Police Service available at: http://www.police.qld.gov.au/ (accessed 21 January 2011).

Sedlacek, W. E., Benjamin, E., Schlosser, L. Z., and Sheu, H. B. (2007), "Mentoring in academia: Considerations for diverse populations", in Allen, D. \& Eby, L. T. (Eds.), The Blackwell handbook of mentoring: A multiple perspectives approach, Blackwell Malden, MA, pp. 259-280.

Sprafka, H., and Kranda, A. (nd), "Institutionalizing mentoring into police departments", available at: http://www.olemiss.edu/ciss/Academics/Research/Police_Chiefs_Desk_Referen ce/pdf/12\%20mentoring.pdf (accessed 2 November 2010).

Kemper, E, Stringfield, S. \& Teddlie, C (2003), "Mixed methods sampling strategies in social science research", in Tashakkori, A. \& Teddlie, C. (Eds.), Handbook of mixed methods in social and behavioral research. Sage Publications: Thousand Oaks, Cal., pp. 273-296. 